\title{
TP53 Gene
}

National Cancer Institute

\section{Source}

National Cancer Institute. TP53 Gene. NCI Thesaurus. Code C17359.

This gene plays a critical role in cell cycle regulation and has tumor suppressor activity. 